PAN, Yi. 2017. Rural Welfare in China. New York: Springer International Publishing.

Book reviews

Jing Yang

(2) OpenEdition

Journals

Electronic version

URL: http://journals.openedition.org/chinaperspectives/8934

DOI: 10.4000/chinaperspectives.8934

ISSN: 1996-4617

Publisher

Centre d'étude français sur la Chine contemporaine

Printed version

Date of publication: 20 March 2019

Number of pages: $91-92$

ISSN: 2070-3449

Electronic reference

Jing Yang, «PAN, Yi. 2017. Rural Welfare in China. New York: Springer International Publishing. », China

Perspectives [Online], 2019-1 | 2019, Online since 25 March 2019, connection on 19 December 2020

URL : http://journals.openedition.org/chinaperspectives/8934 ; DOI : https://doi.org/10.4000/

chinaperspectives.8934

This text was automatically generated on 19 December 2020.

(c) All rights reserved 


\section{PAN, Yi. 2017. Rural Welfare in China. New York: Springer International Publishing.}

Book reviews

Jing Yang

1 Authored by Yi Pan, a former senior researcher for the Chinese Ministry of Civil Affairs, Rural Welfare in China seeks to offer a broad view of the evolution and characteristics of Chinese rural welfare from a long historical perspective. First published in Chinese in 2014, the book demonstrates that China's rural welfare system is a combination of traditional culture, state intervention, collectivism, and socialism. It is composed of state, society, and family welfare, whereas in the Western context, it is usually conceived as state-market-individual welfare (p. 11).

2 Chronologically organised into three sections, the book relies on historical literature, information, and data from the Ministry of Civil Affairs of the People's

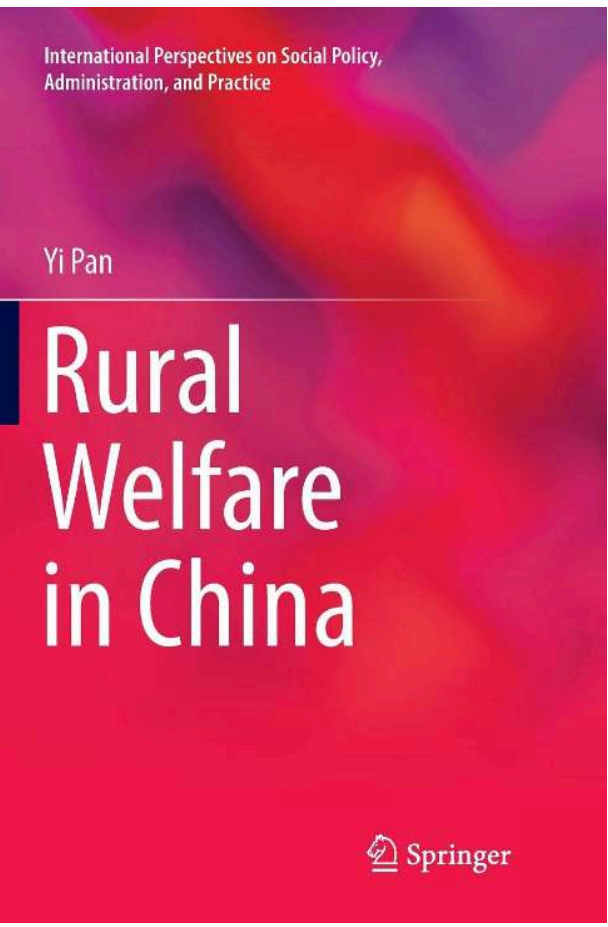
Republic of China.

3 The first part examines traditional welfare culture and the rural welfare system before 1949, showing that it consisted of family, community, state, and cultural tradition. As the most basic unit of welfare supplier, families had the duty of taking care of children and the elderly. The clan (zongzu 宗族) was another blood-relation-based welfare unit 
that retained a family-like function, while being larger than the family itself. The clan established private schools for education and redistributed collective land for poverty relief purposes. The community, composed of several clans according to geographic location, was also an important welfare provider, especially for safety and basic water conservancy. Finally, the state played a vital role by providing land to peasants as well as by regulating the income and subsidies of villagers through tax policies. It also ran a social assistance system that included disaster and poverty relief, elderly subsidies, and grain storage in case of famine, etc.

The second part focuses on rural welfare policy from 1949 to 1978. It mainly analyses how the rural welfare system was established and the principles on which it was based. Influenced by the Soviet Union, China established a similar comprehensive socialist welfare system covering almost all rural groups with various kinds of social security including: land distribution, work income, calamity relief and poverty assistance, the "Five Guarantees" System (of food, clothing, medical insurance, housing, and burial) targeting the most vulnerable groups, a cooperative medical system represented by barefoot doctors, compulsory education, and so on (p. 14). Nevertheless, to avoid a heavy burden on the state budget, this was a low-level protection system implemented mostly by work teams, brigades, and People's Communes, which reflected its collective mutual assistance characteristics (p. 107).

The third section focuses on Chinese rural welfare since 1978. After the implementation of the household contract responsibility system, the People's Communes disappeared, and mutual collective assistance was abandoned. Meanwhile, there were new experimentations: the mutual aid fund, rural pension insurance, and welfare factories that provided jobs for vulnerable and disabled people (p. 113). However, due to the establishment of the Ministry of Social Security in 1998 and the focus on urban reforms, these explorations were not pursued further. From the twenty-first century onwards, the policy has changed, and experiments with welfare conducted in the framework of "re-collectivism" and "re-cooperative" have emerged again in some rural areas.

This book provides an in-depth analysis of the historical background and evolution of the Chinese welfare system. It not only emphasises the importance of Chinese traditional culture in the evolution of the welfare system but also provides detailed analyses of welfare policies and institutions, such as the traditional grain storage system, water conservation, and disaster and poverty relief measures. As a result, the author provides a useful bridge between historical welfare culture and current institutions, and contributes to the growing literature on East Asian welfare.

7 Many scholars argue that China's rural welfare retrogressed between 1978 and 1998 (Li, Jiang, and Chen 2008), and Yi Pan, who was involved in the implementation of social security reform, does not evade the topic; the book offers insights into this phase of rural welfare retrenchment as well as shedding light on why some new experiments failed. Moreover, it elaborates on rural pension experiments in a few developed areas such as Shanghai and Beijing, which is helpful to grasp the current state of China's rural welfare system.

Regrettably, discussion of the roles played by family and state are not conducted in greater detail throughout the book. Families and communities did not always operate harmoniously, and there was an extreme gender inequality regarding responsibility for care within families. In a society following a patrilocal residence tradition, daughtersin-law were the main caregivers. Nowadays, daughters and daughters-in-laws still take 
care of the elderly more than sons and sons-in-law (Ma 2011), and three-quarters of elderly care is provided by women (Liang and Li 2010). This gender inequality in family care has seriously affected the career development of women. Meanwhile, in traditional Chinese society, the power of the state below the county level was very weak (Fei 1999); administrative organisations could hardly reach the townships or rural areas (Wen 1999). The state was a safety net that acted only in times of severe disasters as an emergency response.

In summary, Rural Welfare in China provides a comprehensive overview and detailed material for scholars and students who want to understand the evolution of China's rural welfare system. Its long historical perspective would be useful to graduate students in East Asian studies, welfare, social assistance, poverty, and social policy

\section{BIBLIOGRAPHY}

FEI, Xiaotong 费孝通. 1999. “再论双轨政治” (Zai lun shuanggui zhengzhi, Rethinking the double track politics). In Fei Xiaotong 费孝通, 费孝通文集第四卷 (Fei Xiaotong wenji di si juan, Collected Works of Xiaotong Fei Vol. 4). Beijing: Group Press. 343-64.

LI, Ling 李玲, JIANG Yu 江宇, and CHEN Qiu-lin 陈秋霖. 2008. “改革开放背景下的我国医改30 年” (Gaige kaifang Beijing xia de woguo yigai sanshi nian, A review of China's health care reform after the reform and opening policy in 1978). Chinese Health Economics 27(2): 5-9.

LIANG, Li-xia 梁丽霞, and LI Wei-feng 李伟峰. 2010. “社会性别视阈下的老年人家庭照顾问题研 究” (Shehui xingbie shiyu xia de laonianren jiating zhaogu wenti yanjiu, Study on the problem of family care for elderly from a gender perspective). Journal of Jinan University 20(6): 67-70.

MA, Yan 马炎. 2011. “对老年人家庭照顾者的社会性别研究评述” (Dui laonianren jiating zhaoguzhe de shehui xingbie yanjiu pingshu, Commentaries on gender studies in family caregivers). Journal of China Women's University 23(2): 37-43.

WEN, Tiejun 温铁军. 1999. “半个世纪的农村制度变迁” (Bange shiji de nongcun zhidu bianqian, Rural institutional change over the past 50 years). Strategy and Management 6: 76-82.

\section{AUTHOR}

\section{JING YANG}

Jing Yang is a doctoral candidate in economy at École des Hautes Études en Sciences Sociales (the School for Advanced Studies in the Social Sciences).cherryjeune@gmail.com 